\title{
TOURISM DEVELOPMENT IMPACT ON THE ECONOMY OF AZERBAIJAN
}

\author{
Naila MUSAYEVA¹, Irena SILINEVICA² \\ 1Phd student, Azerbaijan Tourism and Management University, Baku, Azerbaijan, \\ e-mail: naila_musayeva@yahoo.com, phone: +994 503596708 \\ ${ }^{2}$ Dr.sc.ing., professor, Rezekne Academy of Technologies, Rezekne, Latvia, \\ e-mail: irena.silinevica@ru.lv, phone:+371 29103480
}

\begin{abstract}
The aim of this research is to explore tourism development impact on the economy of Azerbaijan. International tourism as a source of both direct and indirect incomes of the state encourages the development of different sectors not specific to the tourism infrastructure, but through the multiplier effect. In this context, the authors analyze the impact of tourism on employment in Azerbaijan and calculate the indirect impact of tourism on the economy of Azerbaijan due to the multiplier effect. The development of tourism in Azerbaijan is constrained by a number of factors, some of which have been analyzed in the paper. Moreover, based on some of the models and data available in Azerbaijan tourism statistics, the authors assess the indirect impact of tourism on the economy in a long term. The results can be used to assess the overall impact of tourism on the economy of the state; to forecast the development of the tourism industry; to forecast the development of related industries; to assess indirect effects of tourism on the growth of population welfare; to forecast the dynamics of change and the efficient use of labour resources; to develop an investment industry strategy; to develop an effective system of taxation, etc.. The following research methods were used: content analysis of tourism development documents, statistical data analysis; comparative analysis, synthesis, abstract and logical construction methods for studying tourism development opportunities.
\end{abstract}

Keywords: tourism; economic development, GDP, employment Jel Code: 01; 0180; J680

\section{Introduction}

Rich historical, cultural, and natural heritage in Azerbaijan attracts tourists from all over the world. Azerbaijan is characterized by wilderness, a rich flora and fauna, numerous sources of minerals, ancient architecture, a kind of national culture and national cuisine, geological monuments like mud volcanoes, deep gorges, waterfalls. It is an area with 11 climate zones, where you can relax in all seasons. Azerbaijan has great potential for tourism development with its rich historical and cultural heritage, natural resources. These resources are the factors of the further development of tourism. In Azerbaijan, the direct impact of tourism is taken into account on the economy as a whole with a relatively high degree of reliability. Tourism is a source of both direct and indirect revenues of the state, encourages the development of various sectors, not specific to the tourism 
infrastructure, but through a multiplier effect. This sphere impacts employment as well.

The aim of this research is to explore tourism development impact on the economy of Azerbaijan. To achieve this aim, several tasks were defined:

- to analyse the impact of tourism on employment in Azerbaijan;

- to analyse the indirect impact of tourism on the economy of Azerbaijan due to the multiplier effect;

- to work out proposals for the development of tourism in Azerbaijan.

The research subject: the factors influencing tourism development in Azerbaijan.

The hypothesis of this research: it is possible to increase the share of the tourism industry in the gross domestic product (GDP) of Azerbaijan.

Novelty: There are analysed the impact of tourism on employment and the indirect impact of tourism on the economy of Azerbaijan due to the multiplier effect.

The developed recommendations can be used to assess the overall impact of tourism on the economy of the state; to forecast the development of the tourism industry; to forecast the development of related industries; to assess indirect effects of tourism on the growth of population welfare; to forecast the dynamics of change and the efficient use of labour resources; to develop an investment industry strategy; to develop an effective system of taxation, etc.

To accomplish the objectives of this research study, the following research methods were used: content analysis of tourism development documents, statistical data analysis; comparative analysis, synthesis, abstract and logical construction methods for studying tourism development opportunities.

\section{Research results}

\section{The impact of tourism on employment in Azerbaijan}

Since 2003, the unemployment rate in Azerbaijan is evaluated not only by the number of the officially registered unemployed, but also according to ILO methodology. The ILO-Comparable estimates are based on full coverage surveys and present the employment and unemployment estimates in standard age groups for the core active ages, to minimise noncomparability related to differences in minimum or maximum age limits. To avoid inconsistencies associated with the use of different reference periods, the ILO-Comparable statistics are adjusted and expressed in terms of annual averages (IX ILO-Comparable..., 2012). 
The number of the unemployed from 2002 to 2012 decreased by 195.5 thousand and was 243.1 thousand people. Successfully conducted by the state, employment policy plays an important role in reducing the number of the unemployed (Джавадова Р.Д., 2010).

The role of economic entities in the tourism industry, including hotel management in solving problems of employment is undeniable.

In Azerbaijan's tourism the average number of workers employed directly, including those employed in the hotel industry, and those who have specialized in accommodation facilities directly in the tourism industry annually increases. At the same time, it is difficult to understand what data should be included in the employment statistics, since workers, for example, hotels and restaurants not only serve tourists. The employment rate is higher in the resorts that are in great demand.

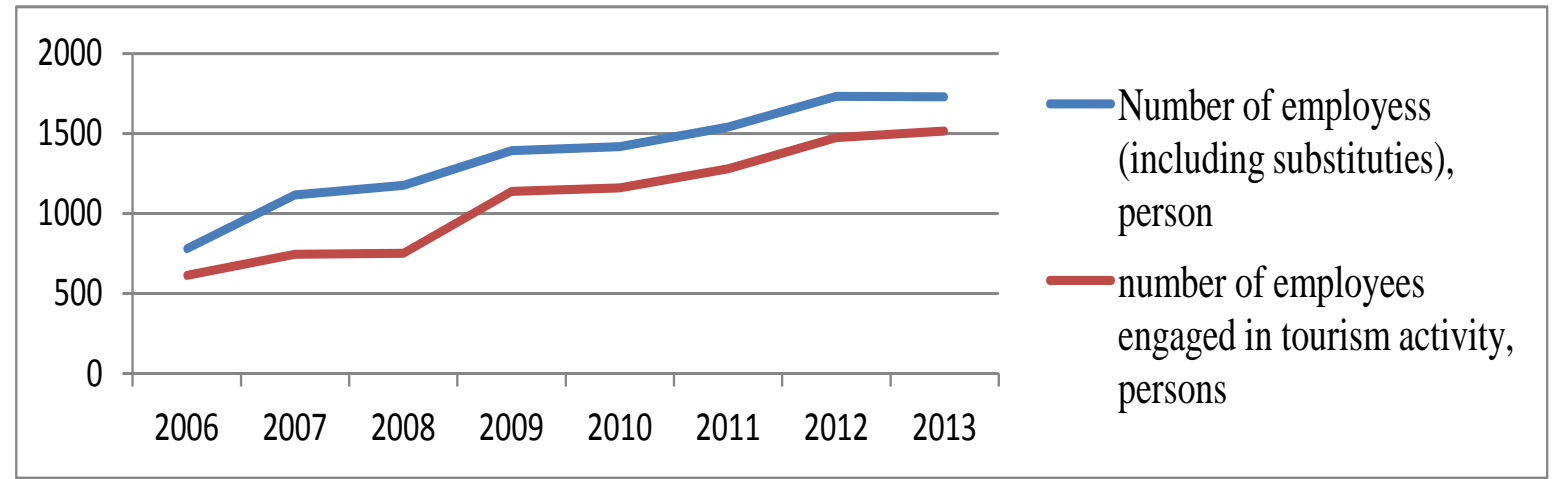

Figure 1. The dynamics of employment indicators in the field of tourism in Azerbaijan (Source: World and regional statistics..., 2015)

In 2013, rapidly growing demand for tourism services has led to an increase in the proportion of the employed population by $13 \%$ from the total population in comparison with 2002 . The level of economic activity of the entire population during the study period increased by $7.3 \%$ and totalled 4.6 million people. The dynamics of employment in absolute terms was 514.2 thousand people. As a result, the dynamics of the economic activity of the labor force outstrips the number of workforce itself (World and regional statistics..., 2015).

Currently 7321 people are working in accommodation facilities. The number of employees in the past six years increased by about $65 \%$. In 2012 the costs of accommodation enterprises on salaries were 27389.2 thousand manats. The average monthly salary of workers in the sphere of hotel business in 2012 was approximately 310 manats; the salary has increased by $26.5 \%$ since 2011 . In the same year, the average monthly 
salary in the country was 397 manats (World and regional statistics..., 2015).

\section{The indirect impact of tourism on the economy of Azerbaijan due to the multiplier effect}

In Azerbaijan, the direct impact of tourism is taken into account on the economy as a whole with a relatively high degree of reliability. The calculation of the indirect effect of tourism is made possible through the use of a multiplier - a scalar indirect impact of tourism on the economy and social sphere of the state. The multiplicative effect of tourism is the most important, which is caused by the specifics of the industry, as well as the presence of "invisible export" paradox (Rzaev, R. R., Rzaeva, I. R., 2005)

The indirect impact of tourism on the economy depends not only on tourist expenditure in their place of residence, but also on the tendency of resource accumulation by the population and businesses involved in the present cycle. The higher is a tendency to accumulate, the lower is the value of the multiplier effect. Therefore, it is believed that a tourist multiplier for a particular region - a factor reflecting the increase in indirect revenues in the region, depending on the tourist expenditures. If the tendency of resource accumulation by the population and enterprises in one particularly selected region is assumed constant, an increase in the multiplier effect of tourism is necessary: the development of the tourism industry and infrastructure in the region; availability of rich and ecofriendly tourism resources; regional economic development and its consumer sphere; a good tourist image of the region; unlimited supply of import-substituting goods and services; free entry and exit of tourists in the region, etc. Since the main components in a multiplicative effect are tourist expenditures, the economic and legal policy in the region should be aimed at their maximum stimulation.

Tourist expenses in a particular place of residence is a revenue of tourism enterprises, transport companies, trade, consumer services, telecommunications, the business field of leisure and entertainment, etc. These revenues are an additional profit for investment, salaries, jobs etc. Moreover, for the budgets of all levels they induce additional taxes, fees, charges and fees. Then, on the next turnover cycle, they mean additional income of the company invested in its development that, in fact, leads to additional revenue for companies supplying equipment and materials, construction and implement etc. Such cyclical assets turnover: cost income - expenses - revenues - ..., with certain reservations, can be described as a simplified model (Gulajev, V.G., 2008). 


$$
Y=I /(1-M P C),
$$

where I - investments, which are defined as the costs of tourists; MPS marginal propensity to consume. Marginal propensity to consume of the region (country), which is defined as the ratio of the change in the population consumption $« \Delta \mathrm{B} »$ for a certain period to the level of change in income $« \Delta \mathrm{D} »$, causing a change during this interval of time: $\mathrm{MPC}=\Delta \mathrm{B} / \Delta \mathrm{D}$ In this case, a multiplier is

$$
\lambda=1 /(1-M P C),
$$

that, in terms of $\delta=\mathrm{MPC}$, is the sum of an infinitely decreasing geometric progression

$$
\lambda=\delta+\delta^{2}+\delta^{3}+\ldots+\delta^{n}, n=1,2, \ldots
$$

If it is considered that for each additional unit consumed the conditional $\delta$ is the increase in revenue in the first circulation of money, then the $\mathrm{n}$-th step of calculating an increase of $\delta^{\mathrm{n}}$. Using the equation (3), it is possible to count the number of turnovers of tourist spent funds (transactions). Moreover, based on the model (1) and data available in Azerbaijan tourism statistics (Data of the State Committee of Statistics of the Republic of Azerbaijan for 2013, 2015), there should be assessed the indirect impact of tourism on the economy in a long term.

The average marginal propensity to consume is 0.7775 . However, more than a refined MSP value is less than the average country level of 4.9\%. Therefore, in further calculations MSP is assumed to be in the value of 0.7394 or $73.94 \%$. Next, using the calculated multiplier model, it can be obtained that

$$
\lambda=1 /(1-M S P)=1 /(1-0,7394)=3,84,
$$

where on the basis of the equation (3), the multiplier effect of spending per tourist will be

$$
\begin{gathered}
701 /(1-0,7394)= \\
701+0,7394^{*} 701+0,7394^{2 *} 701+0,7394^{3 * 701+\ldots+0,7394 n * 701}=2690
\end{gathered}
$$

In this case, the average expenditure generates an additional income of $\$ 701$ a year per tourist in the country providing $\$ 2690$ in the city budget, making it at about 15 circles. The latter is easy to check if it is taken into consideration that starting with $\mathrm{n}>14$, the funds remaining in 
circulation are very small, i.e., the inequality $0.7394 n \cdot 701<10$ for all $n>$ 14.

At the same time, it should be recognized that the obtained value of the tourist multiplier does not reflect a number of factors affecting it downward. A more accurate value of the multiplier can be obtained on the basis of its generalized differentiated model (Gulajev, V.G., 2008), which takes into account corrective (clarifying) factors. However, the existing methods of statistical data in the field of domestic tourism do not allow taking into account exogenous factors of the model in its entirety.

The multiplier can be corrected downwards for $15-40 \%$ if the standards of the International Classification of Tourism Activities (SIKTA) and on the basis of recommendations by the World Tourism Organization (WTO) Statistics of Tourism and the United Nations on the scale of Azerbaijan is taken into consideration. This means that the real value of the multiplier for the tourism of Azerbaijan will be in the range $2.304 \div$ 3.264. Therefore, the average value of $\lambda=2.784$, which allows to adjust the indicators of tourism development in Azerbaijan in the medium and long term at the stage of preliminary estimates. (Gulajev, V.G., 2008)

The results can be used to assess the overall impact of tourism on the economy of the state; to forecast the development of the tourism industry; to forecast the development of related industries; to assess indirect effects of tourism on the growth of population welfare; to forecast the dynamics of change and the efficient use of labour resources; to develop an investment industry strategy; to develop an effective system of taxation, etc.

\section{Conclusions and suggestions}

Azerbaijan is characterized by wilderness, a rich flora and fauna, numerous sources of minerals, ancient architecture, a kind of national culture and national cuisine, geological monuments, as mud volcanoes, deep gorges, waterfalls. It is an area with 11 climate zones, where you can relax in all seasons. Azerbaijan has great potential for tourism development.

Tourism is a source of both direct and indirect revenues of the state, encourages the development of various sectors, not specifically related to the tourism infrastructure, but through a multiplier effect. The tourism sector in Azerbaijan is developing day by day, becoming one of the most important sectors of the economy.

More faster growth of tourism can be encouraged by the development of a tourism development marketing strategy in Azerbaijan. New ways for tourism growth reveal collaboration opportunities: more close 
cooperation between the public and private sectors in the development of tourism products and tourism infrastructure; more close cooperation between tourism business sectors and education institutions that provide tourism study programmes, in human resource development for improving the service level in the tourism industry.

\section{References}

1. RZAEV, R.R., RZAEVA, I.R., (2005). Indirect influence of tourism to Azerbaijan economy by multiplicative effect. Transaction of Azerbaijan National Academy of Sciences, Series of Physical-Technical and Mathematical Sciences: Informatics and Control Problems, Vol. XXV, No.3.

2. ГУЛЯЕВ В.Г. (2008). Туризм: экономика и социальное развитие. М.: Финансы и статистика.

3. ГУСЕЙНОВ Ш.Р. (2014). Факторы, определяющие туристический потенциал Азербайджана. Управление экономическими системами.

4. Данные Государственного Комитета Статистки Азербайджанской Республики за 2013-й, $2015 . \quad$ (05.04.2016.r.). Получено из http://www.azstat.org/indexaz.php

5. ДЖАВАДОВА Р.Д. (2010). Статистические исследования экономической активности населения в Азербайджане. Российское предпринимательство. № 12 Bыn. 2 (174), 169-174.

6. ШВЕЦ Ю.Ю. (2011). Анализ факторов инновационного развития сферы туризма. Ученые записки Таврического национального университета им. В.И. Вернадского, Серия «Экономика и управление». Том 24 (63), 118-126.

7. World and regional statistics, national data, maps, rankings. Retrieved April, 29, 2015, from: World Data Atlas: http://knoema.com/atlas/ topics/Tourism

8. IX ILO-Comparable annual employment and unemployment estimates (2012). Retrieved Februar 22, 2016, from: http://laborsta.ilo.org/applv8/data/iloce.pdf 


\title{
TŪRISMA ATTĪSTĪBAS IETEKME UZ AZERBAIDŽĀNAS EKONOMIKU
}

\author{
Naila MUSAYEVA¹, Irēna SILINEVIČCA \\ 1 Azerbaidžānas Tūrisma un Vadības universitāte, doktorante \\ ${ }^{2}$ Dr.sc.ing., Rēzeknes Tehnoloǵiju akadēmija, profesore
}

\section{Kopsavilkums}

Azerbaidžāna ir atpazīstama ar savu neskarto dabu, bagāto floru un faunu, neskaitāmiem minerālvielu avotiem, seno arhitektūru, savdabīgo nacionālo kultūru un nacionālo virtuvi, geologiskajiem pieminekḷiem, kā dubḷu vulkāniem, dziḷām aizām, ūdenskritumiem. Tā ir teritorija ar 11 klimatiskām zonām, kur var atpūsties visos gadalaikos. Azerbaidžānā ir liels potenciāls tūrisma attīstībai.

Pētījumā tiek analizēta tūrisma ietekme uz nodarbinātību Azerbaidžānā, aprēḳināta netiešā tūrisma ietekme uz ekonomiku multiplikatīvā efekta rezultātā. Pamatojoties uz pēdējiem datiem, kas pieejami Azerbaidžānas tūrisma statistikā, ir izvērtēta netiešā tūrisma ietekme uz ekonomiku ilgtermiṇā. Pētījuma rezultātus var izmantot, lai novērtētu kopējo tūrisma ietekmi uz valsts ekonomiku, prognozēt tūrisma nozares attīstību, kā arī saistīto nozaru attīstību, izvērtēt netiešo tūrisma ietekmi uz iedzīvotāju labklājības izaugsmi; prognozēt izmaiṇu dinamiku darba resursu racionālai izmantošanai, kā arī izstrādāt tūrisma nozares stratēǵiju, izstrādāt efektīvu nodokḷu sistēmu u.c.

Atslēgas vārdi: tūrisms, ekonomiskā attīstība, IKP, nodarbinātība. 